FACULDADE DE ECONOMIA, CONTABILIDADE E CIÊNCIA DA INFORMAÇÃO E DOCUMENTAÇÃO (FACE).

PROGRAMA DE PÓS-GRADUAÇÃO EM ADMINISTRAÇÃO - PPGA

\author{
ONILDO RODRIGUES SOARES
}

\title{
OS IMPACTOS QUE OS DECRETOS DE CONTINGENCIAMENTO CAUSAM AO DESEMPENHO DAS AGÊNCIAS REGULADORAS FEDERAIS.
}

Brasília - DF 


\section{ONILDO RODRIGUES SOARES}

\section{OS IMPACTOS QUE OS DECRETOS DE CONTINGENCIAMENTO CAUSAM AO DESEMPENHO DAS AGÊNCIAS REGULADORAS FEDERAIS.}

Monografia apresentada ao Departamento de Administração da Faculdade de Economia, Administração, Contabilidade e Ciência da Informação e Documentação (FACE), da Universidade de Brasília, como requisito parcial à obtenção do grau de Especialista em Orçamento e Finanças.

Orientador: Prof. Gilvan Dantas 


\section{Brasília - DF \\ 2009 \\ LISTA DE GRÁFICOS}

Gráfico 1 - Contingenciamento na ANATEL- 2002

Gráfico 2 - Variação dos Orçamentos da ANP de 2001 para 2002

Gráfico 3 - Despesa estimada x receita estimada ANP/2005

Gráfico 4 - Contingenciamento dos recursos da ANATEL/1999.

Gráfico 5 - Percentual de recursos contingenciados - 2003/ANP 


\section{SUMÁRIO}

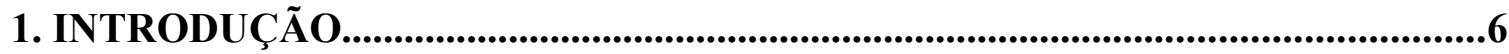

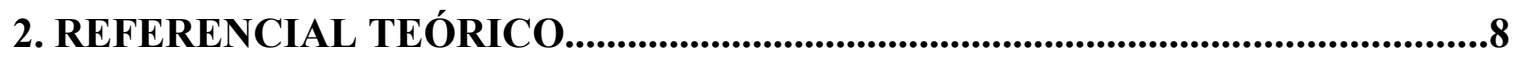

2.1. Finalidade dos decretos de contingenciamento..........................................................

2.2. Finalidade das Agências Reguladoras Federais...........................................................13

2.2.1. Criações de algumas agências importantes.....................................................13

2.2.2. A questão da autonomia das Agências Reguladoras...........................................14

2.2.3. Atribuições das Agências Reguladoras............................................................16

2.2.4. Importância das Agências Reguladoras............................................................. 17

2.2.5. Receitas das agências reguladoras...............................................................18

2.2.6. Propósito da criação das Agências Reguladoras...............................................18

2.3. Ingerência do poder político nas reguladoras federais...............................................21

3. METODOLOGIA.....................................................................................................25

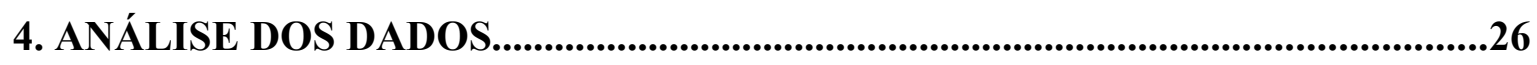

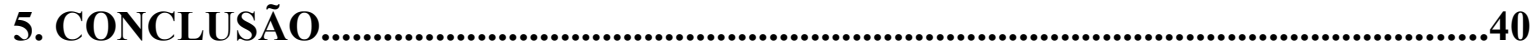

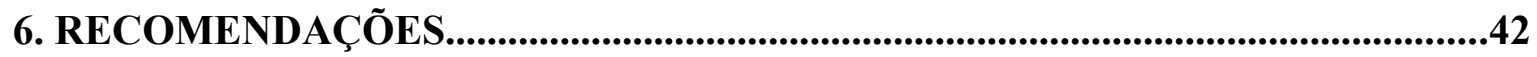

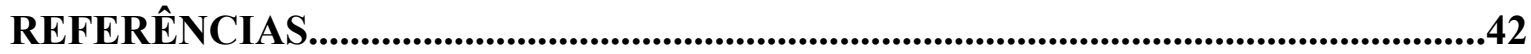





\section{RESUMO}

Trata-se da análise dos impactos que os decretos de contingenciamento causam ao desempenho das agências reguladoras federais. Inicialmente, discute-se o motivo pelo qual esses decretos de contingenciamento são editados e alcançam as receitas das agências reguladoras federais, uma vez que essas entidades são importantes para a regulação dos serviços públicos que foram privatizados. E em item adiante é apresentado o resultado de pesquisa bibliográfica e documental, embasado na discussão inicial concluindo que o desempenho das agências tem sido afetado por sucessivos contingenciamentos anualmente editados pelo Governo Federal. Esses impactos se resumem, principalmente, no cancelamento de metas dessas entidades, aprovadas na Lei Orçamentária Anual, (LOA). São, ainda, apresentadas algumas recomendações visando minimizar os efeitos desses contingenciamentos no desempenho das agencias reguladoras federais e outros visando propiciar situações que tornem esses instrumentos menos necessários às finanças públicas do país.

Palavras-chave: Orçamento, Contingenciamento, Metas preestabelecidas. 



\section{INTRODUÇÃO}

Esta monografia foi elaborada conforme trabalho de pesquisa bibliográfica e documental realizada com a finalidade de verificar os impactos que os decretos de contingenciamento causam as agencias reguladoras federais. Para tanto contém seis itens, incluindo esta introdução, organizados conforme se segue.

$\mathrm{O}$ item 2, tratou dos textos utilizados para embasar a pesquisa, denominado referencial teórico contém três partes. A primeira delas versa sobre a finalidade dos decretos de contingenciamento, isto é, procurou-se aqui levantar o motivo pelo qual o Governo edita os decretos de contingenciamento. A segunda parte é destinada à discussão que atualmente se faz em torno das agencias reguladoras federais. Tratou de questões relativas a autonomia, as receitas, as atribuições e enfim da estrutura que se leva em consideração na criação dessas autarquias especiais. E a terceira e última parte destinou-se às ingerências a que estas agências reguladoras estão sujeitas. Procura-se aqui, demonstrar o motivo pelo qual as agencias reguladoras, apesar de que na criação são estruturadas para agir com independência financeira têm as suas receitas bloqueadas pelos chamados decretos de contingenciamentos. Este item contribui para validar a realização da pesquisa.

A partir do referencial teórico chegou-se a definição do elemento de pesquisa, ou seja, do que pode ser considerado um impacto que os decretos de contingenciamento causam às agencias reguladoras federais. Esta definição foi necessária porque a simples edição desses decretos, que é bom que se diga são instrumentos necessários à política macroeconômica do Governo Federal, não necessariamente impacta o desempenho das agencias reguladoras. Verificou-se, no entanto, a ocorrência de alguns tipos de impactos possíveis, sendo o principal deles a não realização de metas estipuladas na Lei Orçamentária Anual - LOA.

Dessa forma, optou-se por uma metodologia de pesquisa, descrita no item 3 deste trabalho, do tipo bibliográfica e documental que atendeu plenamente ao objetivo deste trabalho. E no que se refere à parte documental escolheu como fonte de pesquisa os sítios de agências reguladoras federais e os sítios de entidades de classe dessas agências especializados em dar conhecimento público de atividades desenvolvidas por uma entidade governamental, conforme preconiza o princípio da Transparência dos atos públicos. Foram encontrados relatórios, denominados Rela- 
tórios de Gestão, elaborados pelas próprias agências reguladoras, que analisados contribuíram de maneira direta e precisa para a elucidação da questão de pesquisa formulada.

O resultado da pesquisa, descrito no item 4 - Análise dos Dados destina a traduzir o significado dos dados encontrados em confrontação com os decretos de contingenciamento e com o desempenho das agencias reguladoras. Para tanto, apesar de que os próprios dados já são elucidativas a esse fim, foram incluídos gráficos visando a melhor compreensão dos números obtidos.

Foi apresentada uma conclusão, constante no item 5, enfatizando o resultado que análise dos dados permitiu e, bem como, no item 6 e último deste, foram apresentadas sugestões consideradas pertinentes em razão do tema.

A escolha do tema foi feita considerando que se trata de um assunto de suma importância para as finanças públicas, visou adotar uma pesquisa relacionada às matérias do curso, mas pouco explorado pelo meio acadêmico. Esta importância pode ser medida em função do atual desenvolvimento do país, ou seja, na medida em que metas econômicas estão se tornando marcos históricos de finanças públicas. Segundo declarações de várias autoridades do setor orçamentário, em algum momento, sendo que para alguns esse momento já chegou, o Brasil deverá parar de perseguir essas metas macroeconômicas para melhorar a retribuição que contribuintes devem receber pelos impostos que pagam. Para o autor desta pesquisa, o reconhecimento que esse dia chegou passa pela necessidade de dotar as agências reguladoras federais de recursos necessários para que possam ser agentes do Estado. 


\section{REFERENCIAL TEÓRICO}

\subsection{Finalidade dos Decretos de Contingenciamento}

A Lei de Responsabilidade Fiscal - LRF disciplina o contingenciamento quando trata da "limitação de empenho e movimentação financeira" nos arts. $4^{\circ}$, inciso I, alínea $b$, e $9^{\circ}, \S \S 1^{\circ}$ e $2^{\circ}$, in verbis: Art. $4^{\circ}$. A lei de diretrizes orçamentárias atenderá o disposto no $\S 2^{\circ}$ do art. 165 da Constituição e: I - disporá também sobre:

b) critérios e forma de limitação de empenho (...);

Art. $9^{\circ}$ Se verificado, ao final de um bimestre, que a realização da receita poderá não comportar o cumprimento das metas de resultado primário ou nominal estabelecidas no Anexo de Metas Fiscais, os Poderes e o Ministério Público promoverão, por ato próprio e nos montantes necessários, nos trinta dias subseqüentes, limitação de empenho e movimentação financeira, segundo os critérios fixados pela lei de diretrizes orçamentárias.

$\S 1^{\mathrm{o}}$ No caso de restabelecimento da receita prevista, ainda que parcial, a recomposição das dotações cujos empenhos foram limitados dar-se-á de forma proporcional às reduções efetivadas.

$\S 2^{\circ}$ Não serão objeto de limitação as despesas que constituam obrigações constitucionais e legais do ente, inclusive aquelas destinadas ao pagamento do serviço da dívida, e as ressalvadas pela lei de diretrizes orçamentárias.

Portanto, segundo se pode extrair da LRF, pode-se definir o Contingenciamento como um retardamento ou uma inexecução de parte da programação de despesa prevista na Lei Orçamentária. É editado através de decreto normalmente no início do exercício. Trata-se do bloqueio de parte dos valores autorizados na Lei Orçamentária, relativos às despesas discricionárias ou não legalmente obrigatórias (investimentos e custeio em geral).

A LRF, aprovada em 2000 pelo Congresso, trouxe responsabilidades para o administrador público no que tange aos orçamentos da União, dos Estados e municípios, impondo limite de gastos com pessoal, proibindo a criação de despesas de duração continuada sem contrapartida de receitas, entre outros. A Lei introduziu a restrição orçamentária na legislação brasileira e cria a disciplina fiscal para os três poderes. Não obstante essa importância, essa lei é tida como um dos pi- 
lares da política macroeconômica do Governo Federal. Há certa unanimidade em torno da aceitação dela quando se trata do objetivo de equilibrar o orçamento. No entanto, com o passar dos anos começa a aparecer o questionamento quando ao fato dela representar um "engessamento" da economia que impede o país de buscar maiores taxas de crescimento.

Segundo Carvalho e Lepikson (2006) "uma crença atual é a que existe apenas uma política macroeconômica, tecnicamente fundamentada e neutra. Assim, não há mais espaço para políticas de direita ou de esquerda". Novelli (2008) destaca que "o governo Lula é um governo neoliberal; é o terceiro mandato de Cardoso" ao se referir à continuidade da política macroeconômica.

Estas críticas referem-se, mesmo que indiretamente, a LRF, uma vez que ela foi considerada no governo anterior e continua sendo no atual o pilar da política macroeconômica. E não há como contestar essa firmação a luz do seu art. $9^{\circ}$.

“Art. $9^{\circ}$ Se verificado, ao final de um bimestre, que a realização da receita poderá não comportar o cumprimento das metas de resultado primário ou nominal estabelecidas no Anexo de Metas Fiscais, os Poderes e o Ministério Público promoverão, por ato próprio e nos montantes necessários, nos trinta dias subseqüentes, limitação de empenho e movimentação financeira, segundo os critérios fixados pela lei de diretrizes orçamentárias". (BRASIL, 2000).

O texto do art. $9^{\circ}$ da LRF não estabelece percentual de meta de superávit a ser perseguido. É previsto o cumprimento da meta fixada na Lei de Diretrizes Orçamentárias. Portanto, a meta de superávit a ser cumprida é determinada pelos responsáveis para política macroeconômica do Governo. O problema é que esta fixação de valores para esta meta tem sido alta. Segundo Novelli (2008), isso se deve à necessidade de sustentação do valor externo da moeda, necessária para atrair investimentos externos, que somente vieram para o Brasil em razão da diferença entre as taxas de juros, norte-americana, e a brasileira. Ou seja, a alta meta de superávit primário, definida na LDO é uma garantia documentada aos investidores de que o capital investido por eles será remunerado acima da taxa de mercado mundial. Esta é uma política destinada a atrair investidores para o país, que se iniciou com o Governo Cardoso e teve continuidade no governo Lula. Apesar do Governo Lula, no discurso, ter feito pesadas críticas a política macroeconômica do Governo 
Cardoso, na prática ele a adotou. Vejamos o que destaca Novelli (2008) sobre as declarações do governo Lula a respeito da política do governo Cardoso.

Ao tomar posso em $1^{\circ}$. de janeiro de 2003, o governo Lula responsabilizou o governo Cardoso pela dureza das medidas adotadas. A assim chamada "herança maldita" consistia, internamente, no alto endividamento público que correspondia a $29,2 \%$ do PIB em 31 de dezembro de 1994 (um dia antes da posse de Cardoso) e que atingiu 55,9 do PIB em 31 de dezembro de 2002 (último dia de seu governo). Essa enorme dívida está diretamente relacionada ao Plano Real implementado por Cardoso quando era Ministro da Fazenda do governo Itamar Franco (1992-1994). Como se sabe, o Brasil conviveu com altas taxas anuais de inflação (superiores a 100\%) desde 1980 e todas as tentativas anteriores ao Plano Real para alcançar a estabilidade de preços fracassaram. O "sucesso" do Plano Real em controlar a inflação deve ser creditado à conjuntura de alta liquidez no mercado internacional de capitais em 1994, que permitiu a fixação do valor externo da moeda como forma para atingir a estabilidade do seu valor interno" (NOVELLI, 2008)

Portanto, essa continuidade atesta a eficiência da política macroeconômica, mas o seu custo é alto demais para o país, pois se trata de manter a estabilidade econômica via manutenção de juros altos. Esse custo, no governo Cardoso contou com recursos extras advindo das privatizações e de aumentos sistemáticos da carga tributária, pois havia margem para isso. Agora, essa política está sendo financiada via cortes de programas aprovados na LOA. Essa é a finalidade dos decretos de contingenciamento.

\subsubsection{Contingenciamento de 2008}

Visando garantir superávit primário e recursos para o Fundo Soberano, o governo deixou de lado a execução de verbas para investimentos no país. A crítica é do Instituto de Estudos Socioeconômicos (Inesc), apresentada em nota técnica da entidade, em resposta aos cortes no orçamento anunciados pelo ministro do Planejamento, Orçamento e Gestão, Paulo Bernardo. 
"Enquanto o recorde de superávit primário é batido até agora, é crítica a situação de execução orçamentária de 2008", afirma o documento. De acordo com o Inesc, dados do Sistema Integrado de Administração Financeira do Governo Federal (Siafi) apontam que até 26 de junho - a poucos dias do encerramento do semestre - a execução atingiu "somente 33,58\%" do orçamento total autorizado.

A entidade classifica de "irrisória" a execução de recursos de algumas funções do orçamento, principalmente, as voltadas para "promoção e garantia de direitos", entre elas, Direitos e Cidadania, (11\% dos recursos executados), Cultura (10,83\%), Saneamento (2,73\%), Organização Agrária (5,9\%) e Gestão Ambiental (9,27\%), por exemplo.

No entanto, o texto reconhece que o período de eleições, em que os gastos ficam subordinados aos prazos previstos pela legislação eleitoral, e a aprovação tardia da Lei Orçamentária pelo Congresso Nacional - em meados de março - podem ter dificultado a execução dos recursos.

\subsubsection{Contingenciamento de 2009 .}

O Governo Federal limitou através do Decreto $\mathrm{n}^{0}$ 6.808, de 27/03/2009 a movimentação e empenho e de desembolso financeiro para a Administração Pública Federal para o exercício de 2009. Este decreto é uma alteração do contingenciamento anteriormente feito. A alegação para essa alteração é a previsão da redução do crescimento econômico em 2009 de 3,5\% para 2\% do PIB. Além disso, o Governo alega que a arrecadação de receitas primárias sofrerão uma redução da ordem de $6,4 \%$, caindo dos previstos $\mathrm{R} \$ 808,9$ bilhões para $\mathrm{R} \$ 756,9$, ou seja, haverá uma perda de receita da ordem de $\mathrm{R} \$ 51,9$ bilhões.

Em decorrência, reduziu-se as transferências a estados e municípios de $\mathrm{R} \$ 143,2$ bilhões para R \$ 127,3 bilhões (ou seja, R \$ 15,9 bilhões) e as receitas da União líquidas de transferências e exceto a Contribuição para a RGPS passou de R \$ 617,4 bilhões para $\mathrm{R} \$ 576,0$ bilhões, representando uma redução de $\mathrm{R}$ \$ 41,4 bilhões em comparação à que consta da LOA/2009.

O Governo Federal prevê redução para as despesas obrigatórias de $\mathrm{R} \$ 180,4$ bilhões para R \$178,6 bilhões. Essa diferença de R \$1,8 bilhão refere à redução no cronograma de pagamentos de subsídios, subvenções e Proagro ( $\mathrm{R}$ \$ 5,3 bilhões) e nos gastos com pessoal e en- 
cargos sociais (R\$ 1, bilhão), mesmo tendo ocorrido aumento das despesas proveniente da reabertura dos créditos especiais (R\$ 3,0 bilhões), da liberação de projetos em carteira dos fundos FDA/ FNDE (R\$ 1,2 bilhão) e da fabricação de cédulas e moedas (R \$ 600 milhões) para consecução da política monetária.

No que diz respeito ao Regime Geral da Previdência Social, a projeção atual considera que o déficit reduzirá de $\mathrm{R} \$ 40,8$ bilhões para $\mathrm{R} \$ 40,1$ bilhões, ou seja, menos $\mathrm{R} \$ 755,3$ milhões).

Apesar do superávit primário ter se mantido em 3,85\% do PIB (a redução da taxa de crescimento, acarretará uma redução do superávit de R $\$ 67,8$ bilhões para $\mathrm{R} \$ 66,4$ bilhões, ou seja R \$ 1,4 bilhão a menos) como previsto na LOA/2009, na prática, será de 3,3\%, pois o Governo pretende usar, pela primeira vez, $0,5 \%$ do PIB (R\$ 15,5 bilhões) para custear o Projeto Piloto de Investimento - PPI (que contém boa parte dos recursos do PAC).

O valor do contingenciamento, portanto, foi de $\mathrm{R} \$ 21,6$ bilhões, equivalente a 14,3\% das despesas discricionárias de custeio e de investimento ( $\mathrm{R} \$ 151,1$ bilhões). O contingenciamento dos Órgãos e Unidades Orçamentárias, no valor total de R\$ 25,1 bilhões, pode ser observado no Quadro 01 a seguir. O Governo, mediante portaria ministerial poderá ampliar esses limites de movimentação e empenho em até R \$ 3,7 bilhões.

Em termos nominais as receitas estimadas para 2009 são superiores as obtidas em 2008 que foram de R\$ 717,4 bilhões. As receitas administradas estão estimadas em R \$ 485,0 bilhões.

O Governo prevê também a redução do crescimento da massa salarial de 12,95\% para 6,29\%, do preço do barril de petróleo de U\$ 76,37 para U\$ 47,27, da taxa de juros de $13,57 \%$ para $10,8 \%$ e o aumento da inflação (IGP-DI) de $4,16 \%$ para 5,8\% e da taxa de câmbio de $\mathrm{R} \$ 2,04$ para $\mathrm{R} \$ 2,30$.

O corte total realizado pelo Governo em 2008 foi de R\$19,2 bilhões, dos quais R\$ 12,3 bilhões foram em investimentos e R \$ 6,9 bilhões em custeio. O corte preventivo promovido pelo Decreto $\mathrm{n}^{\mathrm{o}} 6.752$, de 28/01/2009, foi da ordem de $\mathrm{R} \$ 37,2$ bilhões, de um total de $\mathrm{R} \$ 148,5$ bilhões contido na LOA/2009 (equivalente a uma redução de 25\%). Até a semana passada esse corte seria de $\mathrm{R} \$ 21,6$ bilhões.

As menores limitações de despesas foram nos Ministérios da Saúde $(1,4 \%)$ e da Educação (7,7\%) e os maiores cortes ocorreram nos Ministérios do Turismo (86,4 \%) e do Esporte $(84,4 \%)$. 
O contingenciamento atingiu também aos Poderes Legislativo (R \$ 91,3 bilhões), Judiciário (R\$ 214,2 milhões) e Ministério Público da União (R\$ 27 milhões), equivalente a um total de R\$332,5 milhões.

Não foram utilizados recursos do Fundo Soberano do Brasil (R\$ 14,2 bilhões) para manutenção das metas fiscais.

\subsection{Finalidade das Agências Reguladoras}

\subsubsection{Criações de algumas agências importantes}

Segundo a Lei de Concessões № 8.987 de 1995 as agências devem ser estruturadas quando de suas criações na forma de autarquia a fim de ter condições ideais para proteger os consumidores de serviços públicos, repassados pelo Estado à iniciativa privada.

Dentro dessa premissa a Agência Nacional de Energia Elétrica (ANEEL), foi a primeira a ser criada, através da Lei $\mathrm{N}^{\circ}$ 9.246, de 26 de dezembro de 1996 e regulamentada por decreto de $n^{\circ}$ 2.335, de 06.10.97, com atribuições de regular e fiscalizar a geração, transmissão, distribuição e comercialização de energia elétrica.

Seguiram-se as criações das agências: Agência Nacional do Petróleo - ANP, lei de criação 9.478, de 6 de agosto de 1997; Agência Nacional de Telecomunicações - ANATEL, lei de criação 9.472, de 16 de julho de 1997; e mais recentemente a Agência Nacional de Vigilância Sanitária, ANVS, Agência Nacional de Saúde - ANS e Agência Nacional de Águas - ANA e etc. Espera -se para breve a criação de uma agência reguladora para o mercado de capitais. Especulase, também, a conversão do Banco Central em uma agência de regulação.

“O modelo de agência reguladora aplicada no Brasil é baseado no modelo norteamericano, quando as agências atingiram seu maior grau de poder. As agências reguladoras estão sendo criadas de um modo muito cuidadoso, onde é preservada sua independência em relação ao Poder Executivo, como forma de torná-las isentas de pressões políticas. Em virtude disso, contam com um alto grau autonomia, inclusive 
financeira, pois são dotadas de verbas próprias. Suas decisões são tomadas por um órgão colegiado. Seus diretores-gerais tem mandato fixo, e além de serem indicados pelo Presidente da República, devem passar por uma sabatina perante o Senado Federal. COIMBRA (2001).

\subsubsection{A questão da autonomia das Agências Reguladoras}

Tendo em vista os recentes acontecimentos envolvendo a Agência Nacional de Aviação Civil, torna-se importante discutir a questão da autonomia das agências reguladoras.

Segundo Abranches (1999):

"O primeiro projeto de criação de uma agência reguladora - ANNEL, do setor de
energia elétrica - foi enviado pelo Executivo federal ao Congresso no final de 1995,
seguindo o modelo de autarquia convencial - sem autonomia decisória nem
independência financeira. Coube ao Congresso a iniciativa de questionamento do
modelo tradicional e a busca de modelos alternativos, a partir da experiência
internacional. Outro ator relevante foi o Conselho de Reforma do Estado, órgão
consultivo de asessoria ao Presidente da República, formado por intelectuais e figuras
públicas. Em sua primeira resolução, adotada no início de 1996, o Conselho de Reforma
do Estado sugeria critérios e princípios a serem adotados pelo marco regulatório e para a
criação das novas organizações reguladoras, dentre eles: a autonomia e independência
decisória do ente regulador por meio de mandatos fixos para os dirigentes e não
coincidentes com o Executivo; a decisão colegiada, precedida de ampla e prévia consulta
pública sobre as normas a serem editadas, junto ao setor regulado e aos usuários; a
agilidade processual; o estabelecimento de níveis desejáveis de prestação do serviço (ABRANCHES,1999)

Segundo Azevedo (2007) "Adotando-se um modelo neoliberal, baseado na redução do papel do Estado na esfera econômica e social, surgem as Agências Reguladoras como medida de descentralização institucional". Segundo esse autor, com o advento da Constituição de 1988, criou-se um novo modelo para a exploração direta de atividade econômica pelo agente pri- 
vado, resguardando, porém, ao Estado às funções de fiscalização. Nesse contexto, surgem às agências reguladoras, com características de desburocratização, autonomia normativa e financeira, independência (em relação à Administração direta e com suas decisões revistas apenas pelo Poder Judiciário), tecnicidade (dirigentes especializados no setor regulado), consenso para dirimir conflitos (decisões colegiadas), ou seja, relevante instrumento de adequação de uma nova ordem jurídico-econômica. Tal processo iniciou-se no governo Collor, prosseguiu de forma mais tênue no governo Itamar, até quer no governo FHC, diante da decisão de se privatizar empresas do governo criou-se as agências reguladoras nos setores de telecomunicações ANATEL, petróleo e bio-combustíveis ANP, saúde suplementar ANS, vigilância sanitária ANVISA, cinema ANCINE, águas ANA, transportes terrestres e aquaviários ANTT e ANTAQ e energia elétrica ANEEL.

Entretanto, o presidente Lula, ao iniciar o seu primeiro mandato, tentou devolver a regulação e fiscalização aos respectivos Ministérios. Tal tentativa foi mal recebida pelo mercado e pela crítica especializada, uma vez que a concepção das agências reguladoras é tratar questões técnicas por meio da técnica, e não pelo viés político.

Contudo, de maneira indireta, o governo Lula praticamente esvazia e limita a atuação das agências reguladoras. Primeiramente, com a falta do repasse de dotações orçamentárias dos respectivos Ministérios às agências, o que compromete sobremaneira a atuação das agências, especialmente quanto à fiscalização do mercado e dos agentes regulados. Depois, com a ausência de nomeação de dirigentes para as agências, que deveriam ocupar o lugar daqueles que tinham o mandato encerrado. Diversas agências ficaram sem o quorum mínimo para decidir questões importantes para o desenvolvimento do País e para o bem-estar econômico dos consumidores. Quando novos dirigentes eram indicados, muitas vezes ao invés da técnica prevaleciam aspectos políticos, e assim eram aprovados e legitimados pelo Senado Federal e nomeados pelo Presidente da República.

Por fim, o maior revés às agências reguladoras, ocorre com o despacho do Presidente da República em 2006 ao aprovar o Parecer da Advocacia-Geral da União, que analisando a divergência entre o Ministério dos Transportes e a Agência Nacional de Transportes Aquaviários (ANTAQ) reconhece o "recurso hierárquico impróprio", algo que interfere decisivamente na autonomia e na independência das agências reguladoras. Permite-se com tal recurso a revisão ministerial de decisões tomadas pelas agências, sob a alegação de que "a aferição da autonomia das agências e de suas condutas além de diretamente vinculadas às suas finalidades institucionais se mede principalmente pela adequada compatibilização com as políticas públicas adotadas pelo 
Presidente da República e os Ministérios que o auxiliam”. Com isso, decisões técnicas podem ser tratadas de forma política, trazendo insegurança jurídica aos administrados e inibindo investimentos para o desenvolvimento sócio-econômico do País.

Ressalta-se que a autonomia das agências reguladoras em relação ao Poder Legislativo é bastante reduzida. O legislador pode interferir na agência alterando seu regime jurídico e até extingui-la. Pode ainda fiscalizá-la e suspender seus atos normativos não condizentes com a Lei, tudo em conformidade com o Estado Democrático de Direito, já que a própria Constituição Federal não assegura a independência absoluta das agências. Outrossim, as agências têm sua autonomia e independência, balizadas por "standards" jurídicos, quais sejam, a Lei instituidora da Agência e, sobretudo, a Constituição Federal. Qualquer desrespeito a esses valores assegurados em Lei, o Poder Judiciário está apto a intervir na decisão da Agência.

Quanto ao caráter técnico da atuação das agências reguladoras, uma vez que regulam mercados específicos, a indicação dos dirigentes das agências pelo Poder Executivo, a aprovação pelo Senado Federal e a nomeação pelo Presidente da República deve, portanto, observar o conhecimento técnico que esses dirigentes possuem do setor em que atuarão. Os dirigentes somente perderão o mandato em caso de renúncia, de condenação judicial transitada em julgado ou de processo administrativo disciplinar, salvo outra previsão contida na lei de criação da agência. O mandato garante a autonomia e independência do dirigente contra pressões políticas. Todavia, diante do que vem ocorrendo, restringiu-se demasiadamente a autonomia e a independência das agências reguladoras no Brasil, comprometendo a regulação econômica; algo prejudicial à livre concorrência, ao bem-estar econômico do consumidor e ao desenvolvimento do País. É nesta realidade de enfraquecimento das agências reguladoras que a Agência Nacional de Aviação Civil (ANAC) foi criada em 2005 para substituir o Departamento de Aviação Civil (DAC) e regular e fiscalizar as atividades de aviação civil e de infra-estrutura aeronáutica e aeroportuária.

\subsubsection{Atribuições das Agências Reguladoras}

A atuação das agências reguladoras segue os institutos e princípios da Administração Pública. Segundo Meirelles (1995, p. 385) o controle da Administração "em tema de admi- 
nistração pública, é faculdade de vigilância, orientação e correção que um Poder, órgão ou autoridade exerce sobre a conduta funcional de outro".

Assim, cabem a elas tanto as atribuições de concessão/permissão/ autorização de serviço público à iniciativa privada como também a regulação. Inicialmente, elas escolhem o permissionário/concessionário através procedimento licitatório e com ele celebra o respectivo contrato definindo o valor de tarifa e sua revisão/reajuste, conforme o caso. Após isso seguirá regulando os atos desses concessionários/permissionários através da aplicação de sanções, do exercício do papel de ouvidor de denúncias e reclamações recebidas dos usuários. Enfim as agências reguladoras recebem prerrogativas conferidas pela lei ao poder público em decorrência da concessão ou permissão.

\subsubsection{Importância das Agências Reguladoras}

As agências reguladoras regulam a prestação de serviços públicos prestados por particulares. Segundo CARVALHO (2002), “A outorga aos entes privados, do direito de explorar atividade essencialmente pública, se deu através da Lei de Concessões dos serviços públicos, que regula a concessão destes serviços até então exercidos pelo Estado". Ainda segundo CARVALHO (2002):

A função regulatória é essencial para a eficiência do processo de desestatização, pois na maioria das vezes trata-se de processo complexo que são realizados mediante contratos de longo prazo.Isso faz com que ocorram mudanças inesperadas no curso do contrato, que deve ser adaptado a nova realidade mediante o julgamento isento dos princípios que o norteiam CARVALHO (2002).

Conforme BARROSO (2002):

“A constatação de que o Estado não tem recursos suficientes para todos os investimentos necessários e que, além disso, é geralmente um mau administrador, conduziu ao processo de transferência para o setor privado da execução de ampla gama de serviços 
públicos. Mas o fato de determinados serviços públicos serem prestados por empresas privadas concessionárias não modifica a sua natureza pública ${ }^{(17)}$ : o Estado conserva responsabilidades e deveres em relação à sua prestação adequada. Daí a privatização haver trazido drástica transformação no papel do Estado: em lugar de protagonista na execução dos serviços, suas funções passam a ser as de planejamento, regulação e fiscalização. É nesse contexto histórico que surgem, como personagens fundamentais, as agências reguladoras" BARROSO (2002).

Os autores supracitados são unânimes em afirmar que a importância das Agências Reguladoras está na necessidade de regular o serviço público prestado por empresas concessionárias.

\subsubsection{Receitas das Agências Reguladoras}

Segundo CARVALHO (2002) "é fundamental para a garantia da autonomia das agências reguladoras, e a independência financeira, que ocorre através de mecanismo de atribuição de receita, sem que o recurso tenha que passar pelo erário público”.

Segundo Pereira (1997), as agências reguladoras devem ser mais autônomas do que as executivas, porque não existem para realizar políticas de governo, mas para executar uma função mais permanente que é essa de substituir-se aos mercados competitivos.

\subsubsection{Propósito da criação das Agências Reguladoras}

Conforme a EBAPE/FGV - Núcleo de Estudo de Regulação, em 1887, nos Estados Unidos foi criada a Comissão Interestadual de Comércio, primeira agência reguladora daquele país. A Inglaterra criou a Autoridade Independente para a Televisão, em 1954 e, no bojo das reformas da Primeira Ministra Thatcher, várias outras agências foram criadas começando pela OFTEL (Telecomunicações) em 1984. Na França, por exigência da União Européia foi criada a 
Autoridade de Regulação das Telecomunicações -ART e em 1997 e a Comissão de Regulação da Eletricidade - CRT, em 2000.

No Brasil, a primeira agência reguladora autarquia, isto é, entidade descentralizada dotada de autonomia gerencial foi criada nos anos trinta, no governo de Getulio Vargas para servir de instrumento de superação da crise provocada, em 1929, pela quebra da Bolsa de Nova York. Foram criadas as agências reguladoras da produção e do comércio dos produtos mais relevantes da pauta exportadora brasileira: o Departamento Nacional do Café, depois IBC, e o Instituto do Açúcar e do Álcool, criados em 1933, e os Institutos Nacionais do Mate (1938), do Sal (1940), e do Pinho (1941). Mais tarde, usufrui do mesmo status a Comissão Nacional de Energia Nuclear (1956), o Conselho Administrativo de Defesa Econômica - CADE (1962) e o Banco Central (1964).

Em 1996 deu-se a criação da ANEEL, primeira agência reguladora dos tempos atuais. Depois vieram a ANATEL, a ANP , a ANVISA (vigilância sanitária, 1999), ANS (planos de saúde suplementar, 2000), a ANA (recursos hídricos, 2000), ANTT (transporte rodoviário e ferroviário, 2001) e a ANTAQ (portos e transportes por água, 2001).

Em todos os casos se reconhece que a função regulatória é uma atividade essencial e inalienável do Estado. O propósito que está por trás da criação das novas agências é a necessidade de dar especialização e eficiência a essa função. Elas fazem parte da estrutura estatal, mas considera-se mais conveniente estabelecer um órgão especificamente dedicado à atividade, com pessoal especializado na tarefa, com carreiras estruturadas e com estruturas mais ágeis do que as grandes máquinas ministeriais. Em todos casos acima mencionados, as agências são dotadas de autonomia com o propósito de colocar certas questões fora dos propósitos políticos de curto prazo, para dar continuidade às políticas e ao planejamento de longo prazo e para dotar de isenção às adjudicações, evitando assim as suspeitas de favorecimento. Tudo isso em prol da defesa do interesse público que deve ser o norte permanente da ação reguladora.

É verdade que as agências brasileiras padeceram de uma série de problemas decorrentes da falta de experiência e cultura regulatórias e das filosofias vigentes na época de sua criação. Deu-se, por exemplo, ênfase exagerada ao objetivo de defesa de concorrência na crença ingênua de que basta assegurar um mercado em funcionamento para que os direitos dos usuários sejam automaticamente protegidos. Por outra parte, as ações judiciais invocadas contra a o regime jurídico do pessoal das agências, ainda que justificadas na sua reclamação substantiva, impediram os concursos e, conseqüentemente, a formação e consolidação de quadros de reguladores. 
Mais ainda, a falta de políticas claras emanadas do Poder Executivo, levou as agências a incorrer em domínios alheios à sua alçada a fỉm de assegurar a continuidade do serviço.

Ainda assim elas apresentam uma série de características desejáveis em matéria de gestão democrática, que se coadunam a contento com os pressupostos de cidadania participativa que pautam a atividade pública do novo governo. As leis de criação das agências estabelecem mecanismos de descentralização geográfica e funcional, participação ampla dos atores envolvidos, relações contratuais entre os órgãos administrativos que substituem a tradicional subordinação hierárquica, consideração ampla e clara da participação e dos direitos do usuário-cidadão e outros aspectos técnicos de valia singular.

As atribuições das agências podem ser mudadas. É necessário que os Ministérios cumpram com a função de formuladores de políticas públicas para que as agências desempenhar essas políticas. Só assim, a cultura da regulação se consolidará e será legitimada legitimando pela sociedade. 


\subsection{Ingerência do poder político no desempenho das agências reguladoras federais}

As atribuições das agências são garantir a operacionalização dos contratos de concessão firmados pelo Executivo. Se antes os problemas das telecomunicações eram tratados somente com o Sistema Telebrás, hoje, às comunicações no Brasil se dispersou por cerca de 40 empresas independentes. Nesse caso, portanto, é função da Agência Nacional de Telecomunicações (Anatel), em parceria com o Ministério das Comunicações, observar como cada uma dessas empresas concessionárias de serviços de telefonia, transmissão de imagens e de dados está se comportando no mercado.

Entre as atribuições dessa agência está avalizar a necessidade de novos players para evitar a formação de cartéis ou situações de monopólio, monitora a flutuação das tarifas, procura informar e educar os consumidores sobre seus direitos e deveres. Como também é sua tarefa regulamentação de contratos de prestação de serviços, cobrar os investimentos previstos e checar se as metas de atendimento, expansão e satisfação dos clientes estão sendo atendidas. Em caso de descumprimento, ou abuso de poder econômico ou prejuízo dos consumidores, as agências têm poder para advertir as empresas, aplicar multas e, eventualmente, rescindir contratos.

Como ocorreu ao setor das comunicações, o mercado de diversas áreas, por exemplo, a do petróleo, antes de domínio da Petrobrás, da saúde, do saneamento básico, da energia elétrica e dos transportes, e etc., que se transferiu a iniciativa privada num curto espaço de tempo exigiu um novo tipo de controle de mercado, mais moderno, no qual o papel das agências, embora seja também o de salvaguardar os interesses nacionais, é o de defender os consumidores e as próprias empresas, bem como seus acionistas e investidores. São elas as guardiãs dos chamados marcos regulatórios, ou seja, a garantia jurídica de que as regras do jogo econômico não mudarão e os contratos assinados agora entre o governo e as concessionárias serão respeitados até o fim.

Não é pouco lembrar que, para cumprir com seu papel, as agências reguladoras foram criadas sob a forma jurídica de autarquias, ou seja, órgãos administrativos autônomos, autoadministráveis vinculados à entidade estatal a que pertencem. E na condição de autarquias federais, o diretor-geral é indicado pelo presidente da República e legitimado pelo Congresso para que possa exercer seu cargo com autonomia necessária para não se submeter a interesses políticos, nem mesmo os do partido da situação. 
Mas essa independência das agências, que é a sua característica essencial é também o que existe de mais polêmico sobre elas. Para o governo Lula as agências, ao possuírem esta autonomia, possuem também o poder de administrar a economia nacional.

Primeiramente, devemos lembrar que o controle das agências reguladoras deve ser feito com base nos institutos e princípios da Administração Pública. Conforme ensina o conceituado Meirelles (1995, p. 385), sobre o controle da Administração: "Controle, em tema de administração pública, é faculdade de vigilância, orientação e correção que um Poder, órgão ou autoridade exerce sobre a conduta funcional de outro". Esse controle é feito pelos seguintes órgãos:

Controle legislativo - O controle da Administração Pública pelo parlamento é estabelecida no artigo 49, inciso X da Constituição Federal de 1988. Neste sentido, apesar de seu caráter independente, a atuação das agências reguladoras federais deve ser fiscalizada pelo Congresso Nacional, devendo prestar esclarecimentos de seus atos quando requeridos.

Controle do Tribunal de Contas - Novamente conforme lição de Meirelles (1995, p. 584/585), a atuação do Tribunal de Contas no controle externo da administração financeira e orçamentária torna-os auxiliares dos Legislativos e colaboradores do Executivo.

"É de se observar que desde a Constituição de 1967 vigora no Brasil uma nova orientação no controle orçamentário e financeiro, visando substituir as meras verificações formais de comprovação da despesa, pelo acompanhamento efetivo da conduta contábil financeira da Administração, quer na execução do orçamento, quer no desenvolvimento dos programas de trabalho. Suprimiram-se os registros da despesa e dos contratos que tanto emperravam a atuação do Executivo, aliviou-se o Tribunal do julgamento de pequenos atos que em nada contribuíam para a probidade administrativa, atribuindo-se-lhe funções de maior relevância e de participação na dinâmica governamental.”

Controle Judicial - Nas palavras ainda de Meirelles (1995, p. 604/605) o conceito de controle judicial:

"Controle judiciário ou judicial é o exercido privativamente pelos órgãos do Poder Judiciários sobre os atos administrativos do Executivo, do Legislativo e do próprio 
Judiciário quando realiza atividade administrativa. É um controle a posteirori, unicamente de legalidade, por restrito à verificação da conformidade do ato com a norma legal que o rege. Mas é sobretudo um meio de preservação de direitos individuais, porque visa a impor a observâncias da lei em cada caso concreto, quando reclamada por seus beneficiários. Esses direitos podem ser públicos ou privados - não importa - mas sempre subjetivos e próprios de quem pede a correção judicial do ato administrativo, salvo ação popular, em que o autor defende o patrimônio da comunidade lesado pela administração".

Controle do Ministério Público - Tal qual todos os órgãos da Administração Pública as agências fiscalizadoras se submetem à fiscalização do Ministério Público realizando prestação de esclarecimentos, quando necessários.

Quanto à subordinação das agências reguladoras ao Poder Executivo, esclarece Kaufmann (2006):

"Teoricamente, as agências reguladoras não poderiam estar vinculadas ao Poder Executivo, para que suas decisões fossem dotadas de imparcialidade e neutralidade necessárias ao atendimento do interesse público. Para a perfeita consecução das atividades a que foram instituídas, deveria haver isenção quanto aos instrumentos de pressão políticos e econômicos; a autonomia financeira, pela arrecadação de tributos específicos, serviria para ampliar a margem de independência das agências reguladoras. Na experiência norte- americana, excluem-se os mecanismos de supervisão e coordenação da atividade regulatória, de modo que suas decisões não se sujeitam à reforma por outra autoridade administrativa. No Brasil, devido à adoção do sistema francês de unidade administrativa, a Administração Pública é composta de maneira hierarquizada, havendo vinculação ou subordinação dos entes que lhe compõem. Destarte, foram as agências brasileiras criadas como autarquias especiais, vinculadas aos Ministérios respectivos, retirando parcela de sua independência, uma vez que os Ministros podem ser livremente nomeados/exonerados pelo Presidente da República.” (KAUFMANN, 2006)

Portanto, as agências reguladoras estão sujeitas a todo tipo de controle e estão subordinadas ao poder executivo. No entanto, prega-se que elas devem atuar com autonomia administrativa e financeira. Ora, não se pode falar em autonomia administrativa para um órgão que se encontra vinculado diretamente a outro. Quanto a autonomia financeira, ela também não 
existe posto que também, na condição de vinculada a o outro órgão superior, os orçamento das agência são controlados pelos respectivos ministérios. 


\section{METODOLOGIA}

Neste trabalho será empregado o tipo de pesquisa bibliográfica e documental. As fontes da primeira serão os artigos, livros e teses que têm servido de substrato para as discussões acerca do tema e que podem ser obtidos em bibliotecas e sítios especializados na internet.

Quanto à pesquisa documental, a origem das informações está centrada, basicamente, nos Relatórios de Gestão das Agencias Reguladoras, nas peças orçamentárias - lei orçamentária e lei de diretrizes orçamentárias -, além de decretos (especialmente os que tratam de contingenciamento ou descontingenciamento de recursos), de medidas provisórias de créditos adicionais que influem diretamente no orçamento. 


\section{ANÁLISE DOS DADOS}

Toda a literatura consultada referente às agências reguladoras é unânime em afirmar que o papel das agencias reguladoras no atual cenário de serviços públicos no Brasil é importante devido às privatizações realizadas a partir notadamente dos anos noventa. As privatizações aconteceram como a solução encontrada pelo próprio ordenamento jurídico para o princípio da descentralização.

O poder público já não tinha condições de realizar investimentos necessários para garantir o fornecimento de serviços públicos com a qualidade exigida no mundo atual quando todos os países precisam acompanhar o desenvolvimento tecnológico. Mas somente repassar serviços para a iniciativa privada não garantiria a qualidade e quantidade de prestação dos serviços. Necessário também fiscalizar os novos prestadores nesse sentido. Fiscalização essa que deveria ser feita com independência financeira e administrativa, ou seja, com isenção política. Contudo, conforme pesquisa realizada nos próprios relatórios de gestão dessas agências reguladoras federais estas entidades não contam com os recursos necessários, ou seja, estas agências não controlam seu próprio orçamento.

Ao contrário de agir com independência, estas agências ainda enfrentam toda a sorte de ingerência por parte do poder público, conforme levantamento efetuado:

1) Além dos decretos de contingenciamento existe um corte importante já na elaboração Lei Orçamentária Anual (LOA), através da formação da Reserva de Contingência. As três principais agências, petróleo, energia elétrica e telecomunicações, perdem muitos recursos quando da aprovação da lei orçamentária, no Tesouro Nacional. Além deste primeiro e principal corte de verbas, os ministérios do Planejamento e da Fazenda fazem outros cortes ou, às vezes, também incrementos, é bem verdade, ao longo do ano, de acordo com a situação operacional dos entes reguladores e de acordo com a arrecadação da União.

2) Quando há liberação de recursos (contra-alegação dos executores da política monetária para justificar o contingenciamento), os gastos, na maioria das vezes, não são feitos, porque os limites para empenho são aumentados até faltar poucos meses para o fim do ano, quando não há tempo hábil para licitar e, assim, os recursos das agências continuam em poder do Tesouro Nacional. A liberação de verbas no fim do ano não permite a implementação dos projetos de investimento e de inventário. 
3) Os constantes contingenciamentos prejudicam de fato os gastos das agências com inventários e fiscalização. Com isso elas perdem as condições de realizar pesquisas e estudos, bem contratar novas concessões ao setor privado. Também têm prejudicado a consolidação dos quadros funcionais dessas agências, pois falta treinamento e a realização de concursos públicos na quantidade necessária para adequar as necessidades dos mercados às capacidades dos entes reguladores de planejar, executar e inventariar.

4) Da maneira como estão sendo tratadas, as agências reguladoras se tornaram apenas grandes arrecadadoras do governo. Elas contribuem com arrecadações de fontes de receitas diversas, como royalties, taxas de fiscalização cobradas dos concessionários e operadores em cada mercado, bônus e outras cobranças de projetos fruto de concessão ou permissão. Através dos contingenciamentos esses recursos acabam servindo para outros fins daqueles para o qual são cobrados da população e das empresas.

Foram detectados vários tipos de impactos que os decretos de contingenciamento causam ao desempenho das agências reguladoras federais: $\mathrm{O}$ maior deles é a perda da independência. $\mathrm{Ou}$ seja, uma vez que as agências têm os seus recursos bloqueados elas deixam de ter autonomia financeira. Assim, a principal autonomia da agencia, a financeira, que nada mais é que a capacidade que a entidade tem de arrecadar e dispor do arrecadado, privilégio que lhe foi atribuído pelo legislador, deixa de existir.

\subsection{Relatórios das Agências}

\subsubsection{Relatório de Gestão - ANATEL 2002}

“A LOA definiu, excluída a reserva de Contingência, o montante de R\$ 558,6 milhões para as despesas da Anatel. O Decreto 4.120/2002, que contingenciou R\$ 172,3 milhões, reduziu esse valor para $\mathrm{R} \$ 386,3$ milhões. (...) Após diversas alterações, por fim o Decreto 4.120 modificado pelo Decreto 4.512 que estabeleceu o valor de R \$ 318,9 milhões como limite para a execução orçamentária e financeira da Anatel.” Página 201 . 


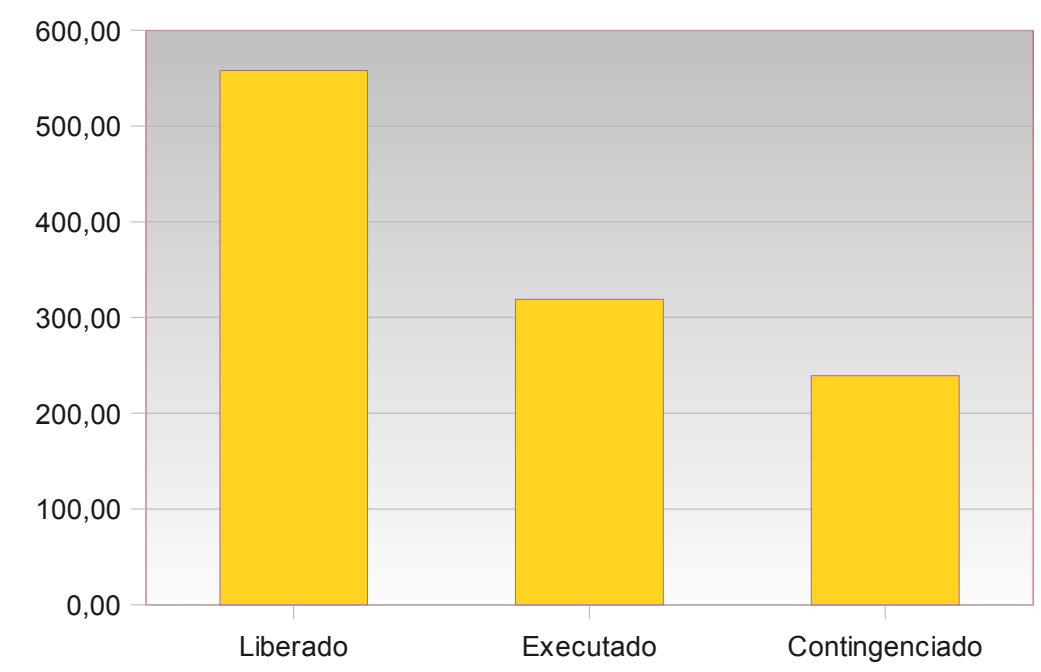

Gráfico 1 - Contingenciamento na ANATEL- 2002

Fonte: Relatório de Gestão ANATEL 2002 - página 201

\subsubsection{Relatório de Gestão - ANATEL 2004}

“A Lei 10.837/2004 - Lei Orçamentária Anual - fixou a despesa da Anatel para 2004 em R \$ 836,9 milhões assim distribuídos: Atividades - R\$ 319,9 milhões (37,2\%) e reserva de Contingência - R\$ 517,0 milhões (62,8\%)”. Página 139. 


\subsubsection{Relatório de Gestão - ANP 2005}

"É importante destacar que apesar de boa parte dos recursos vinculados aos serviços de geologia e geofísica aplicados à prospecção de petróleo continuarem a ser alocados na reserva de contingência, para contribuir com o cumprimento de metas de superávit primário, o governo, atendendo às constantes reivindicações por mais recursos nesta área, incluiu a ação no Projeto-Piloto de Investimentos (PPI).” Página 27.

\subsubsection{Relatório de Gestão - ANP 2002}

“Algumas considerações são necessárias para que se estabeleça uma comparação entre os exercícios de 2001 e 2002, no que respeita a execução orçamentária e financeira. Em primeiro lugar, o total dos dois orçamentos é bem diferente. Enquanto em 2001 a Lei Orçamentária Anual autorizava um total de gastos de R\$ 439.075.895,00, no exercício de 2002 esse montante chegou a $\mathrm{R} \$ 871.433 .434,00$. a diferença decorre exclusivamente da alocação, no orçamento da ANP, de uma Reserva de Contingência de R\$ 442.484.102,00.” Página 24 .

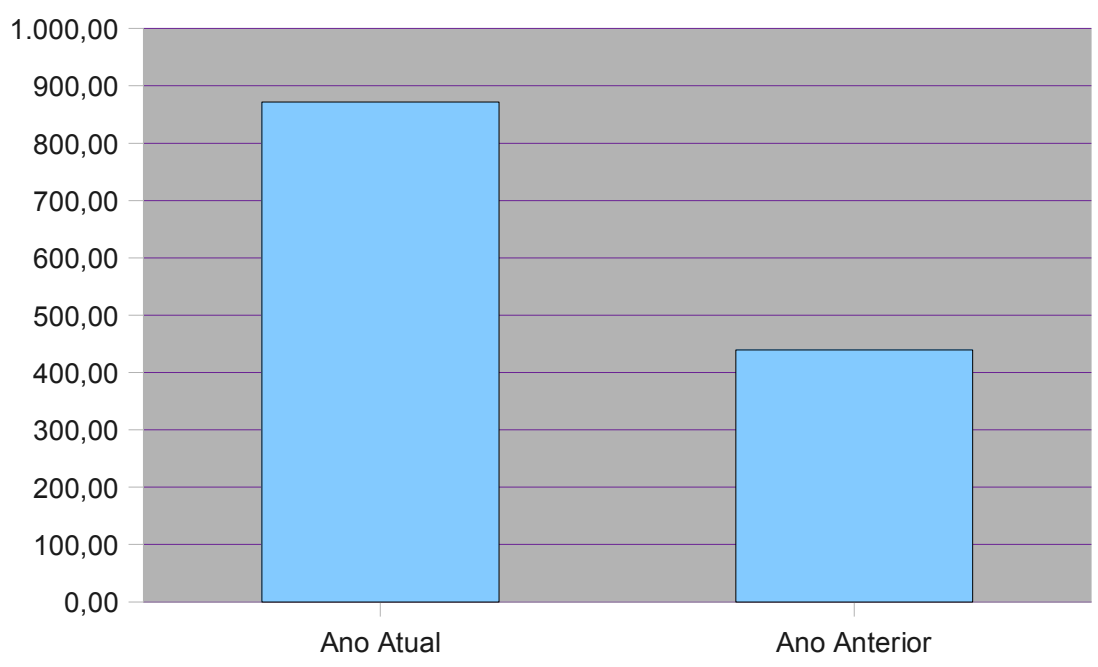

Gráfico 2 - Variação dos Orçamentos da ANP de 2001 para 2002 
Fonte: Relatório de Gestão da ANP 2002, página 24) .

\subsubsection{Relatório de Gestão - ANP 2003}

"Por outro lado, o percentual executado, apesar de ter crescido no período, tem sido influenciado, principalmente nos exercícios de 2002 e 2003, pelas limitações impostas pelos decretos de programação orçamentária e financeira. (...) É bom lembrar que, ao determinar os valores autorizados, não está sendo considerada a Reserva de Contingência, que passou a constar do Orçamento da ANP a partir de 2002, como forma de evitar a alocação para as despesas da agência da totalidade dos recursos previstos no artigo 50 da Lei 9.478/97”. Página 27.

“A execução de 2003 foi fortemente marcada pelo contingenciamento realizado pelos decretos de programação orçamentária e financeira. Comprometido com metas de superávit primário mais elevadas, o Poder Executivo tem imposto restrições cada vez maiores às despesas. (...) Além disso, como forma de evitar a alocação nas despesas da ANP de fontes de recursos vinculados, a exemplo do que ocorreu em 2002, foi estabelecida uma Reserva de Contingência composta exclusivamente dos recursos previstos no inciso I do artigo 50 da Lei 9.478/97 e que serviriam para atender à contratação de estudos e serviços de geologia e geofísica". Página 30 .

"Do total autorizado na LOA para despesas correntes e investimentos, ou seja, $\mathrm{R} \$ 460.972 .674,00$, apenas $\mathrm{R} \$$ 187.158.229,00 (decretos 4.591/03 e 4.847/03) estavam disponíveis no final do ano para movimentação e empenho".

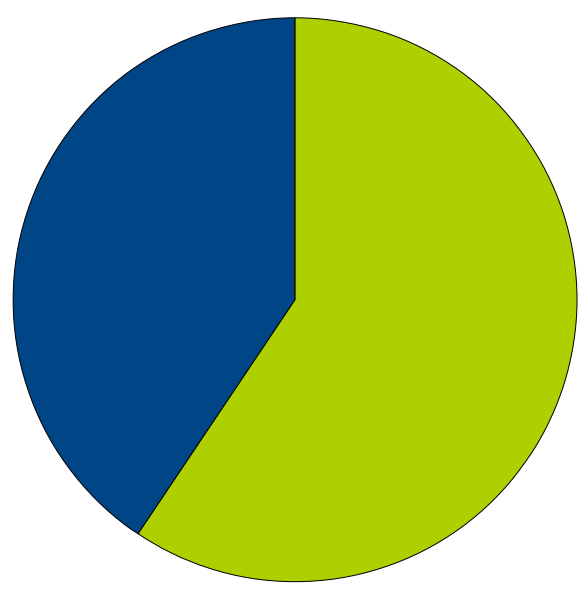

REALIZADO

$\square$ CONTIGENCIADO 
Gráfico 5 - Percentual de recursos contingenciados - 2003/ANP

Fonte: Relatório de Gestão da ANP 2003, página 30.

"Utilizando os macroprocessos como critério de análise de execução, verifica-se que o processo "promover" representou uma parcela considerável da dotação autorizada. Isso porque, a exemplo do que ocorreu com as atividades voltadas para o upstream, também estão contidas as contratações de serviços de geologia e geofísica, que foram pesadamente limitadas em 2003."

\subsubsection{Relatório de Gestão - ANP 2004}

"Se em 2003 a execução do orçamento da ANP foi fortemente influenciada pelo contingenciamento decorrente do decreto de programação orçamentária e financeira, em $2004 \mathrm{o}$ valor consignado para despesas da agência na própria Lei Orçamentária Anual (LOA) partiu de um patamar inferior ao executado no exercício anterior. Para evitar a dotação de recursos para as despesas da ANP, particularmente aqueles vinculados à contratação de estudos e serviços de geologia e geofísica aplicados às bacias sedimentares brasileiras, lançou-se mão da reserva de contingência". Página 35.

“(...) essa execução quase no limite do autorizado nos demais macroprocessos finalísticos revela que a assunção de novos compromissos atingiu um limite que não suporta mais as pesadas restrições que têm sido impostas e que as atuais dotações ao permitem que a agência busque aperfeiçoar e ampliar suas ações”. Página 37.

\subsection{8 - Relatório de Gestão - ANATEL 1999}


“Em 1999, como no ano anterior, a gestão do fundo (Fistel) não foi plenamente exercida pela Agência, como preceitua a Lei Geral de telecomunicações (LGT). Por decorrência, da arrecadação do exercício, no montante de R 2,2 bilhões, parte foi creditada diretamente na conta do Tesouro Nacional - R\$ 1 bilhão - e parte pela Anatel - R \$ 1,2 bilhão.” Item Orçamento.

\subsubsection{Relatório de Gestão - ANP 2005}

"Se por um lado essa medida (inclusão de ações no PPI) representou a alocação de um volume significativo de recursos para a contratação de serviços de geologia e geofísica aplicados à prospecção de petróleo, por outro o valor ainda é muito pequeno em relação ao que está previsto no inciso I do artigo 50 da Lei 9.478/97. Grande proporção destes recursos continua sendo alocada na Reserva de Contingência”. Página 27.

“Com a restrição do limite de movimentação e empenho inicial de R\$ 79.978.260 (- 64\%) durante boa parte do exercício, configurou-se uma situação que reduziu significativamente a capacidade da ANP de expandir suas atividades.” Página 27.

\subsubsection{Relatório de Gestão - ANATEL 2000}

"Somente em 11 de maio de 2000 foi sancionada a Lei Orçamentária Anual LOA- Lei 9.969/2000. para a Anatel, foi estimada a receita no valor de R $\$ 2.341,9$ bilhões e fixada a despesa no montante de R\$ 355,4 milhões.” Item 2.1. 


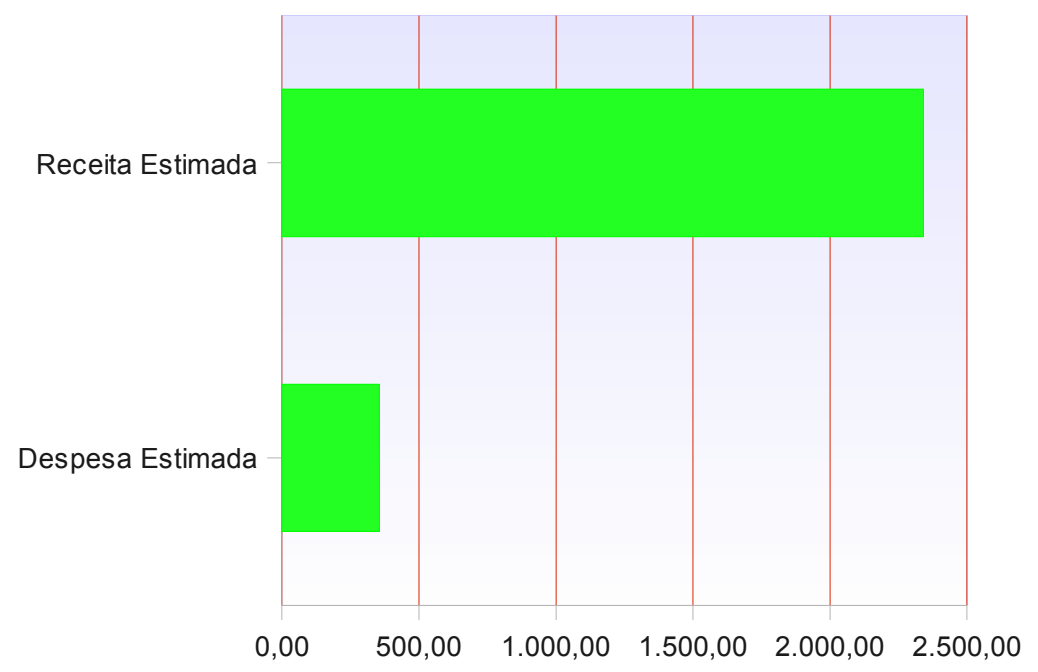

Gráfico 3 - Despesa estimada x receita estimada ANATEL/2000

Fonte:(Relatório de Gestão ANATEL 2000 - item 2.1

\subsubsection{Relatório de Gestão - ANATEL 1999}

No tocante às despesas orçamentárias da Anatel, elas foram estimadas para o exercício de 1999 em R\$ 306,4 milhões. A Lei Orçamentária (9.789/99), no entanto, autorizou apenas R\$ 180,5 milhões”. Página 74.

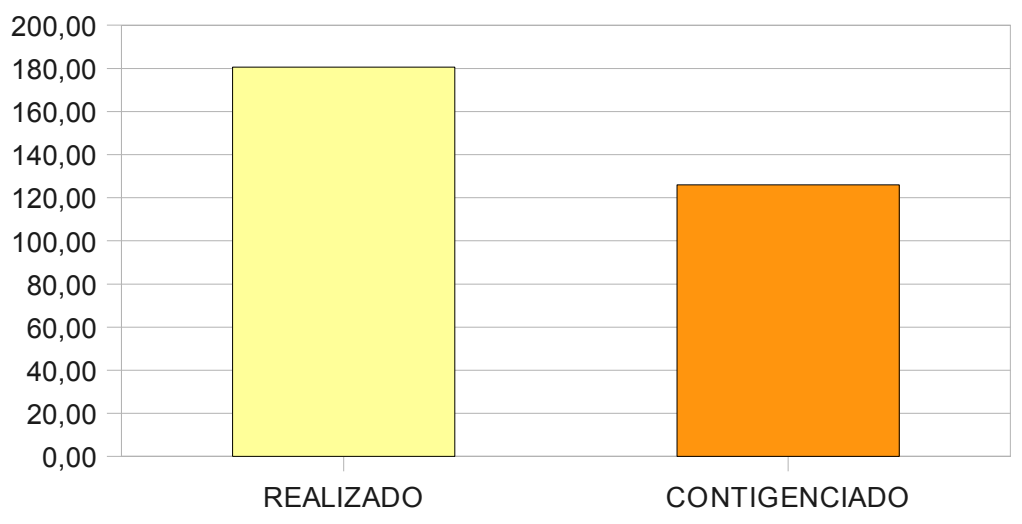


Gráfico 4 - Contingenciamento dos recursos da ANATEL/1999.

Fonte - Relatório de Gestão da ANATEL 1999, item orçamento página 74.

"Pela falta de recursos e por proibição legal (Lei 4.320/84), não pode a agência dar início a vários itens de seu plano de trabalho. Alguns deles deixaram de ser posteriormente executados por terem perdido oportunidade". Página 75.

\subsubsection{Relatório de Gestão - ANELL 7 ANOS - Principais Realizações e}

\section{Desafios.}

"Esse contingenciamento chegou a tal ponto que o Procurador geral do Ministério Público, junto ao Tribunal de Contas da União, dirigiu representação ao presidente daquela corte de contas, solicitando o exame da legalidade dessa restrição. O mais grave, nesta questão, é que os recursos cobrados ao consumidor de energia elétrica, que ficam aplicados numa conta bancária

à disposição da Aneel, sem, contudo, poderem ser aplicados em benefício de quem os paga, já somam mais de R\$ 300 milhões em 2004”. 


\subsubsection{Relatório de Gestão - ANEEL - 2004}

"As restrições orçamentárias comprometeram praticamente todas as atividades programadas. (...) As fiscalizações também foram prejudicadas. Apenas 33 das 64 distribuidoras foram fiscalizadas e somente na etapa envolvendo levantamento de ativos para efeito de revisão tarifária. Os indicadores de qualidade foram monitorados, porém sem fiscalização de campo sobre os dados. O monitoramento a distância da qualidade dos serviços de energia foi afetado na medida em que não foi possível substituir os equipamentos registradores danificados. (...) Também foi reduzido o trabalho da fiscalização da geração: das 180 inspeções em usinas previstas, foram realizadas apenas 30”. Página 77.

“As análises de estudos e projetos das UHEs tiveram atrasos, comprometendo o cumprimento de prazos administrativos e legais, com retardamento dos processos licitatórios." Página 77).

\subsubsection{Relatório de Gestão - ANATEL 2005}

“Apesar de o artigo 51 da LGT preceituar que os recursos do Fistel serão aplicados pela Agência Nacional de Telecomunicações, esses valores não foram disponibilizados para a Anatel, em 2005, na medida de suas necessidades”. Página 35.

“Criado pela Lei 5.070/66), o Fundo de Fiscalização das Telecomunicações (Fistel) é definido como fundo de natureza contábil, destinado a prover recursos para cobrir as despesas na execução da fiscalização dos serviços de telecomunicações, desenvolver os meios e aperfeiçoar a técnica necessária a essa execução. Os recursos do Fistel são, como determina a Lei Geral das Telecomunicações (LGT), aplicados pela Agência Nacional de Telecomunicações.” 


\subsubsection{Relatório de Gestão - ANEEL 2005}

“A principal fonte de receita da Aneel é a Taxa de Fiscalização de Serviços de Energia Elétrica (TFSEE), instituída pela Lei 9.427/1996”. Item 2.2.1.2 .

"Registra-se que, conforme dispõe o Código Tributário Nacional (CTN), espera-se que as despesas com serviços prestados sejam compatíveis com os recursos arrecadados por meio da taxa cobrada pelo exercício do poder de polícia. Assim, a expressiva elevação da receita arrecadada deveria corresponder ao aumento dos recursos disponibilizados para a Aneel". Item 2.2.1.2.

\subsection{Declarações de dirigentes e assessorias de imprensa}

Criadas para intermediar as relações entre os interesses público e privado, principalmente no fim dos anos 90, as agências reguladoras federais sofrem com restrições orçamentárias. Além dos problemas recorrentes de falta de autonomia e de carência de pessoal, as principais delas ainda têm recursos congelados na chamada reserva de contingência. Somente este ano, dos R\$ 8,5 bilhões autorizados em orçamento para uso das reguladoras, cerca de R \$ 6,4 bilhões estão congelados, ou seja, 75\% não podem ser aplicados.

A Agência Nacional do Petróleo (ANP), por exemplo, responsável por fiscalizar postos de combustíveis, entre outras atribuições, tem 93\% dos recursos autorizados em orçamento bloqueados na reserva de contingência. Dos R \$ 3,4 bilhões previstos para a reguladora, quase R\$ 3,2 bilhões não podem ser utilizados, ou seja, não podem servir para pagamento de pessoal, de despesas correntes (luz, água, telefone, etc.) e para investimentos (execução de obras e compra de equipamentos).

O Jornal Nacional mostrou uma série de reportagens na semana passada sobre adulteração de gasolina nos postos de São Paulo. Segundo levantamento do sindicato que representa o setor, em Guarulhos, na Grande São Paulo, por exemplo, os testes indicaram muitas fraudes: dos 400 postos da cidade, 200 vendem gasolina batizada. 
Em entrevista, o coordenador da Agência Nacional do Petróleo em São Paulo, Alcides Amazonas, declarou que a estrutura da ANP é muito precária. "Eu tenho aqui dez agentes de fiscalização para fiscalizar todo o mercado de combustível. Além disso, nós achamos que a legislação precisa endurecer mais. Alguém que adultera combustível não pode continuar no mercado, trabalhando normalmente", disse.

A Agência Nacional de Telecomunicações (Anatel) é outra com orçamento bilionário que tem grande parte da verba concentrada na reserva de contingência. Dos R\$2,8 bilhões autorizados para a reguladora este ano, quase R\$ 2,5 bilhões estão congelados. A quantia bloqueada representa $87 \%$ do montante previsto.

Segundo dados do Sistema Integrado de Administração Financeira (Siafi), o orçamento autorizado para as reguladoras vem crescendo gradativamente desde 2002. No entanto, também é cada vez maior o montante congelado na reserva de contingência. De lá pra cá, as agências reguladoras tiveram dotação autorizada de $\mathrm{R} \$ 43,2$ bilhões (em valores atualizados). No entanto, cerca de $65 \%$ desse montante estavam concentrados na reserva de contingência. Apenas R $\$ 9,2$ bilhões foram efetivamente aplicados pelas entidades, ou seja, menos de $25 \%$ do valor autorizado em orçamento entre 2002 e 2008.

Presidente da Associação Brasileira de Agências de Regulação (Abar), Wanderlino Teixeira de Carvalho, é contra o contingenciamento, independente "até dos altos valores revelados pelos dados do Siafi”. Para a Abar, o valor do montante congelado não importa, pois a questão tem de ser vista pela ótica legal. "Do ponto de vista legal, o contingenciamento é um erro. Fere a lei tratar as taxas, frutos da regulação, como se fossem impostos. A legislação é clara quanto à destinação das taxas resultantes do trabalho do regulador. Elas têm aplicação específica e obrigatória, não podendo, portanto, sofrer contingenciamento. Este é o entendimento da Abar", afirma Carvalho.

De acordo com o presidente da associação, as dificuldades em investir em qualificação e em mais pessoal, por exemplo, estão, evidentemente, ligadas ao contingenciamento. Ele afirma que tais problemas são conseqüência do estrangulamento das agências, especialmente das federais. "Veja que o maior dano é à fiscalização, que acaba aquém da necessidade imposta pelo mercado, enquanto nas agências estaduais não temos notícias de contingenciamento neste nível de interferência", explica.

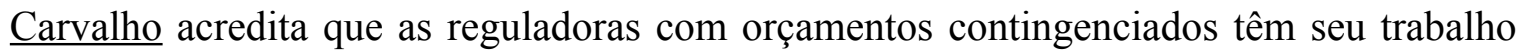
prejudicado e que os recursos aos quais teriam direito poderiam ter muito mais quantidade e 
qualidade nas suas funções regulatórias. "E quem perde é o mercado, onde está o usuário dos serviços públicos, é bom que se diga”, afirma.

“A ANP nega que contingenciamento atinja 93\%. Já a assessoria de imprensa da ANP afirma que os $93 \%$ do orçamento da agência na reserva de contingência são provenientes das participações especiais da reguladora e que, portanto, não serve de parâmetro para avaliar o orçamento da ANP. Segundo a assessoria, um percentual de $28 \%$ das participações especiais foi fixado como receita para a ANP fazer estudos geológicos. "Antes disso, o volume de recursos era muito menor e, mesmo assim, ele nunca foi usado em sua totalidade ou sequer perto dos 50\%".

A assessoria informa que a legislação não previu o aumento da produção e do preço do petróleo, ambos consideráveis nos últimos anos. No entanto, de acordo com a assessoria, a ANP conseguiu um importante acréscimo de recursos este ano para ampliar a área de estudos geológicos de 288 mil quilômetros quad rados, como estava previsto, para 488 mil quilômetros quadrados.

Quanto às reportagens do Jornal Nacional, a assessoria de imprensa da ANP contesta as informações. A agência argumenta que as matérias não mostraram nem dez postos com combustíveis supostamente adulterados, "uma vez que as análises não foram feitas pela ANP e não têm validade legal". A assessoria informa que a ANP-SP vai receber novos servidores para o serviço de fiscalização nas próximas semanas. Além disso, a ANP afirma que renovou por cinco anos o convênio com a prefeitura de SP, que permite a prefeitura também fiscalizar a qualidade dos combustíveis. Segundo a assessoria, o índice de gasolina não-conforme (fora das especificações da ANP) caiu de 10,6\% em abril, para 2,6\% em maio.

Ainda segundo a assessoria da ANP, as agências, como outros órgãos do governo, devem ter os recursos necessários para executar seu trabalho. “Como o Brasil ainda não é um país onde sobram recursos, cabem as agências e a todos no governo trabalhar dentro da realidade orçamentária. A ANP, assim como outras, luta para melhorar seu orçamento, mas também trabalha para gastar melhor os recursos disponíveis, definindo prioridade para os gastos", conclui.

A assessoria de imprensa da Anatel, por sua vez, afirma que não se manifesta a respeito do contingenciamento, "pois se trata de medida de política macroeconômica conduzida pelo Executivo". Segundo a assessoria, para o cumprimento de suas atribuições, a Agência adequa suas despesas ao orçamento disponível e está em contato permanente com as áreas competentes no sentido de obter mais recursos com vistas ao cumprimento de sua missão. "A realidade 
orçamentária atual exige dos gestores públicos responsabilidade e senso de priorização das despesas", afirma.

De acordo com a assessoria, "a Anatel se orienta pelo princípio da eficiência e tenta, de todas as formas, alcançar seus objetivos com o menor dispêndio de recursos possível". A assessoria ressalta ainda que a reguladora tem ações de curto, médio e longo prazos já planejadas, que deverão ser implementadas com a progressiva liberação dos recursos. "Apesar de eventuais dificuldades orçamentárias, a Anatel em momento algum deixou de cumprir a contento suas atribuições legais e sempre esteve à disposição das áreas competentes para demonstrar a necessidade de seus recursos", conclui. 


\section{CONCLUSÃO}

Não há como negar os impactos que os decretos de contingenciamento causam ao desempenho das agências reguladoras. Se por um lado, o Governo Federal alega que os decretos de contingenciamento não prejudicam os desempenhos das agências porque os recursos que elas arrecadam são superiores as suas necessidades, por outro, as próprias agências, através de seus relatórios de gestão informam exatamente o contrário. Entre as atividades que deixam de ser executadas por falta de receitas, descritas nesses relatórios de gestão relacionou-se:

1)Fiscalização.

Os prejuízos que a falta de fiscalização por parte das agencias reguladoras trazem são enormes e não podem ser recuperados. Recentes reportagens da imprensa merecedora de credibilidade comprovaram a sua existência com as amostras das fraudes. Vide o caso da venda de combustível adulterado, em que o consumidor final que não tem como se defender e também o caso do caos aéreo, quando os usuários ficam a mercê do desrespeito das companhias de aviação.

2)Novas concessões e permissões.

Sem novas concessionárias/permissionárias não há como estabelecer concorrência necessária e adequada prestação de serviços. Sem recursos as agências reguladoras não podem executar essa atividade porque segundo as próprias agências falta pessoal especializado para esse fim que não pode ser contratado uma vez que os concursos públicos demoram a ser autorizados (falta autonomia administrativa).

3)Normatização dos serviços públicos.

É importante corrigir falhas do mercado. Ou seja, é uma das atribuições das agências seria atentar aos problemas que acontecem no mercado para corrigi-las. Recentemente a ANATEL normatizou a portabilidade da linha telefônica. Seguindo esse mesmo exemplo, uma infinidade de melhorias poderia ser feita, mas segundo os mesmos relatórios de gestão a edição de simples normas é postergada por falta de pessoal especializado. Neste particular o PROCON, órgão de defesa do consumidor, vêm denunciando recorrentemente que a omissão das agências reguladoras está prejudicando os consumidores.

Uma questão importante é a constatação de que os decretos de contingenciamento são frutos da prática de um método orçamentário que o permite, denominado orçamento autorizativo. Ou seja, não existe por parte do executivo a obrigação de executar o que foi aprovado na LOA. 
Então, surgem propostas visando a adoção do orçamento obrigatório como solução para evitar várias práticas consideradas abusivas por parte do poder executivo. No entanto, é preciso reconhecer que este processo não é fácil como se imagina a princípio. Inicialmente exigiria grande amadurecimento de nosso Legislativo tão acostumado a analisar a responsabilidade alheia, mas tão despreparado para ter a sua responsabilidade analisada. 


\section{RECOMENDAÇÕES}

Relacionamos algumas sugestões no sentido de reduzir o impacto do contingenciamento. Somente relacionamos sugestões que primem pela filosofia da gestão físcal responsável preconizada pela Lei Complementar 101, de 4 de maio de 2000, denominada Lei de Responsabilidade Fiscal:

Recomendamos as Agências Reguladoras.

1) Melhorar a fiscalização e o controle na arrecadação da receita bem como estima-las com mais precisão. Com a arrecadação ineficiente da receita, ocorre, logicamente a sua frustração.

2) Priorizar a execução das despesas incluídas no projeto da LOA.

3) Priorizar os projetos em andamento, pois assim se evita que construções fiquem paralisadas;

Ao Poder Executivo

1) Considerar outras alternativas para compatibilizar receitas e despesas através da intensificação e diversificação da fiscalização a fim de que o contingenciamento possa ser cada vez menor.

2) Excluir dos Decretos de Contingenciamento as Receitas das Agências reguladoras.

3) Melhorar o controle dos Restos a Pagar, uma questão que contribui para que haja pouca transparência nas contas do Governo. Estes controles se dariam através de:

- Rigidez para a inscrição de despesas em restos a pagar, como as já existentes em outras LDOs;

- Prazo determinado para o pagamento de restos a pagar;

- Evitar sempre que possível à pressão para a inscrição de restos a pagar;

4) Instituir margem de erro na definição da meta de superávit primário, para cima e para baixo, bem como as compensações necessárias ao extrapolar esses limites.

5) Definir prazos para a distribuição dos aumentos dos limites financeiros e orçamentários apresentados nos relatórios bimestrais. Sugere-se 2 meses, até a apresentação do novo relatório;

6)Limitar a apresentação de créditos suplementares a despesas discricionárias com recursos provenientes de excesso de arrecadação ou de superávit financeiro de exercícios anteriores, enquanto houver contingenciamento de despesas discricionárias; 
7)Definir regras para o cancelamento de restos a pagar de exercícios anteriores, observando-se, no que couber, os Arts 36, 37 e 38, da Lei 4.320/64.

Por fim, a última recomendação. As agências reguladoras federais devem primar por bons projetos, pois caso contrário às gestões, defendidas neste trabalho, proporcionarão apenas maiores desperdícios públicos. 


\section{BIBLIOGRAFIA}

ABRANCHES, Sérgio. Reforma regulatória: conceitos, experiências e recomendações. Revista do Serviço Público 50(2):19-49 - abr/jun 1999.

ARAÚJO, Alessandra Matos de. Possibilidades de controle social relativo aos serviços públicos essenciais e a urgência de um novo regime fomentador da cultura participativa . Jus Navigandi, Teresina, ano 7, n. 64, abr. 2003. Disponível em: <http://jus2.uol.com.br/doutrina/texto.asp? $\mathrm{id}=3937>$. Acesso em: 23 jan. 2009.

AZEVEDO, Renato Beiriz Brandão de. Medida presidencial abala a autonomia das agências reguladoras . Jus Navigandi, Teresina, ano 11, n. 1525, 4 set. 2007. Disponível em: $<$ http://jus2.uol.com.br/doutrina/texto.asp?id=10362>. Acesso em: 11 fev. 2009.

BARROSO, Luís Roberto. Agências reguladoras. Constituição, transformações do Estado e legitimidade democrática. Jus Navigandi, Teresina, ano 6, n. 59, out. 2002. Disponível em: $<$ http://jus2.uol.com.br/doutrina/texto.asp?id=3209>. Acesso em: 26 jan. 2009.

BRASIL. Ministério do Planejamento, Orçamento e Gestão - Secretaria de Orçamento Federal. Projeto de Lei Orçamentária - Exercício de 2008. Volume I. p. 11 (Anexo I). Disponível em: <https://www.portalsof.planejamento.gov.br/>. Acesso em: 04 jan. 2009.

BRASIL. Presidência da República - Legislação. Lei Complementar 101/2000 - Estabelece normas de finanças públicas voltadas para a responsabilidade na gestão fiscal e dá outras providências. Disponível em: http://www.planalto.gov.br/ccivil_03/Leis/LCP/Lcp101.htm . Acesso em: 04 jan. 2009.

BRASIL. Página do Senado Federal - Portal SIGA BRASIL. Execução Orçamentária e Financeira. Disponível em:

$<$ http://www8.senado.gov.br/businessobjects/enterprise115/desktoplaunch/InfoView/1 ogon/logon>. Acesso em: 05 jan. 2009.

BRASIL. Presidência da República - Legislação. Lei 4320/64 - Estatui Normas Gerais de Direito Financeiro para elaboração e controle dos orçamentos e balanços da União, dos Estados, dos Municípios e do Distrito Federal. Disponível em: http://www.planalto.gov.br/ccivil_03/Leis/L4320.htm. Acesso em: 10 fev. 2009.

BRASIL. Ministério da Fazenda - Tesouro Nacional (Portal SIAFI). Relatórios Resumidos da Execução Orçamentária e de Gestão Fiscal (LRF) dos anos de 2004 a 2007. Disponível em: 
http://www.tesouro.fazenda.gov.br/hp/lei_responsabilidade_fiscal.asp . Acesso em: 04 jan. 2009.

BRASIL. Presidência da República. Constituição Federal. Disponível em:

http://www.planalto.gov.br/ccivil_03/Constituicao/Constitui\%E7ao.htm. Acesso em:

02 mar 2009.

CONTAS ABERTAS. Perguntas Freqüentes. Disponível em:

http://contasabertas.uol.com.br/asp/faq.asp Acesso em 15 de abr de 2009

CARVALHO, Cristiano Martins de. Agências reguladoras . Jus Navigandi, Teresina, ano 6, n. 54, fev. 2002. Disponível em: ttp://jus2.uol.com.br/doutrina/texto.asp?id=2654>. Acesso em: 22 jan. 2009.

COIMBRA, Márcio Chalegre. O Direito Regulatório Brasileiro . Jus Navigandi, Teresina, ano 5, n. 51, out. 2001. Disponível em: <http://jus2.uol.com.br/doutrina/texto.asp?id=2076>. Acesso em: 23 jan. 2009.

HARADA, Kiyoshi. Superávit primário. Trocando em miúdos. Jus Navigandi, Teresina, ano 9, n. 733, 8 jul. 2005. Disponível em: <http://jus2.uol.com.br/doutrina/texto.asp?id=6987>. Acesso em: 05 fev. 2009.

INSTITUTO DE ESTUDOS ECONÔMICOS. Página da Internet. Disponível em: http://www.ebah.com.br/instituto-de-estudos-socioeconomicos-187.html. Acesso em: 15 mai 2009.

PEREIRA, Luiz Carlos Bresser. A Reforma do Estado dos anos 90: Lógica e Mecanismos de Controle. Cadernos MARE da Reforma do Estado. Brasília, D.F: MARE, 1997.

MEIRELLES, Hely Lopes. Direito administrativo brasileiro. 20. ed. São Paulo: Malheiros, 1995.

NOVELLI, José Marcos N. A continuidade da política macroeconômica entre o governo Cardoso e o Governo Lula: uma abordagem sócio Política. Disponível em http://www.apped.org.br//reuniões/29ra//trabalho/67112337-int.plf. Acesso em 23 jan 2009. 
RELATÓRIO DE GESTÃO 2002. Agencia Nacional do Petróleo. Disponível em:

http://www.anp.gov.br/doc/conheca/Relatorio_de_Gestao_ANP_2002.pdf. Acesso em: 22 abr. 2009.

KAUFMANN, Roberta Fragoso Menezes. As agências reguladoras no direito brasileiro . Jus Navigandi, Teresina, ano 10, n. 987, 15 mar. 2006. Disponível em: $<$ http://jus2.uol.com.br/doutrina/texto.asp?id=8101>. Acesso em: 22 abr. 2009. 